\title{
Kil Blok Tuğlalı Bir Yığma Binanın Duvar Kesme Dayanımının N-Schmıdt Cekici ile Belirlenmesi Orhan DOĞAN ${ }^{*}$ \\ ${ }^{1}$ İnşaat Mühendisliği, Mühendislik Fakültesi, Kırıkkale Üniversitesi, Kırıkkale, Türkiye \\ "1 odogan67@ hotmail.com
}

Öz: 2018 Türkiye Bina Deprem Yönetmeliği (TBDY-2018)'ne göre Türkiye'deki mevcut yapı stokunun tamamı deprem kuşağında yer almakta olup, yaklaşık \%50'sinin yığma bina olduğu ve bunların genelde kırsal alanlarda olduğu bilinmektedir. Kentlerdeki mevcut yığma binalar çoğunlukla mühendislik hizmeti görmüşse de tam tersine kırsal alandaki binaların çoğu mühendislik hizmeti görmemiștir. Genel olarak deprem riski içeren bu binaların güçlendirilmesi 6306 sayılı Kentsel Dönüşüm Kanunu ile zorunlu hale getirilmiştir.

Yığma bir binanın deprem riskinin belirlenebilmesi için gerekli olan duvarların kesme dayanımı, örgü tuğlasının boşluk oranına bağlı olarak TDY-2007'inde doğrudan verilirken, TBDY-2018'de örgü harcının basınç dayanımına bağlı olarak verilmektedir. $\mathrm{Bu}$ değerlerin mevcut hasarlı test yöntemlerle belirlenmesi taşıyıcı sisteme oldukça büyük tahribatlara neden olmasının yanı sıra, bina sakinlerine oldukça büyük rahatsızlık vermektedir.

$\mathrm{Bu}$ çalışma ile hasarlı yöntemle ortaya çıkan tüm bu olumsuzlukları ortadan kaldırmak ve duvarın kesme dayanımını belirlemek için yerinde daha hızlı, pratik ve hasarsız bir test yöntemi geliştirmek amaçlanmıştır. Bu amaçla, mevcut harman tuğlalı yığma bir binanın dört farklı katında ASTM C 1531-03 benzeri bir yöntemle duvarın kesme dayanımı belirlenmiş ve ayrıca örgü ve sıva harcının N-Schmidt çekiciyle R okumaları alınmışıı. Hesaplanan eksenel gerilme değerleri ve örgü-sıva harçlarının R değerleriyle, duvarın bulunan kesme dayanımları arasında uyumlu bir denklem ortaya konmuştur.

Anahtar kelimeler: Yığma Bina, Duvar Kesme Dayanımı, Örgü ve Sıva Harcı, Yığma Binalarda Risk Analizi, Harman Tuğlası

\section{Determination Of Slidıng Shear Strength Of A Clay Block Brick Masonary Building Using N- Schmidt Hammer}

\begin{abstract}
According to Turkey Building Earthquake Code (TBDY-2018), it is known that on all of the existing building stock in Turkey is located in the earthquake zone and it is known that about $50 \%$ of them are masonry buildings and these generally take place in rural areas. Although the existing masonry buildings in cities have mostly received engineering services, on the contrary, those in rural areas have not received engineering services. Strengthening these buildings, which generally include earthquake risk, has been made compulsory by the Urban Transformation Law No. 6306.

Sliding shear strength in the existing masonry building which is required to determine the earthquake risk of a masonry building is given directly in the TDY-2007 regulation depending on the brick hollow ratio, while in TBDY-2018 it is given based on the characteristic compressive strength of the mortar. Determination of these values with existing damaged test methods, besides causing considerable destructions to the structural system, causes considerable discomfort to the residents.

With this study, it is aimed to develop a faster, practical and undamaged test method in place to determine the sliding shear strength of the Wall, eliminating all these negativities arising with the damaged method. For this purpose, the sliding shear strength of the wall was determined with a method similar to ASTM C 1531-03 on four different floors of an existing clay brick masonry building, and also R readings of the plaster and mortar were taken with the N-Schmidt hammer. A compliant equation has been put forward between the sliding shear strengths of the wall and the calculated axial stress values and the $\mathrm{R}$ values of the mortar and plaster.
\end{abstract}

Key words: Masonry Building, Sliding Shear Strength, Mortar and Plaster, Risk Analysis in Masonry, Clay Brick

\section{Giriş}

Yığma bina, yapay-doğal blok malzemenin bağlayıcıyla birbirine tutturulması ile oluşan bir yapı türüdür. Genellikle ekstra işçilik gerektirmediğinden, malzeme bakımından kolay ulaşılabilir olmasından, yerel ve doğal

\footnotetext{
* Sorumlu yazar: odogan67@ hotmail.com Yazarların ORCID Numarası: ${ }^{1} 0000000249421725$
} 
malzemelerden üretilmesinden dolayı ekonomik olması gibi avantajlardan dolayı geçmişte çok tercih edilmiş ve günümüzde kırsal bölgelerde tercih edilmektedirler [1]. Ancak taşıyıcısı duvarlar olan bu yapı rijit özellik gösterdiğinden dolayı deprem esnasında yüksek kesme kuvvetine maruz kalmaktadır. Geleneksel yöntemlerle yapılan bu binalarda; blok malzeme, örgü ve sıva harcına göre daha yüksek dayanıma sahip olduğundan, harç malzemesinin mekanik özelikleri duvarın göçme şeklini ve taşıma kapasitesini belirleyen en önemli parametredir $[2,3]$.

Duvarda bağlayıcı olarak kullanılan harç malzemesi su, çimento, kireç ve kum malzemelerinin karışımıyla oluşmaktadır. Geçmişten günümüze kadar incelendiğinden, çimento malzemesinin üretimi ve ulaşılabilirliği arttıkça örgü harcındaki kullanım oranının arttığı gözlemlenmektedir. Ancak harçtaki çimento oranı mekanik özelliklerin belirlenmesinde büyük önem arz ederken, farklı karışım oranları, kullanılan kumun şekli, granülometrisi ve kirlilik oranı, hava koşulları gibi parametreler dayanımı etkilemektedir [4-6]. Tüm bu değişkenlerden dolayı farklı mekanik özellikler gösteren örgü harcı çeşitliliği oluşmakta ve hatta uygulama faktörü ve ortam koşulları göz önüne alındığında aynı bina içerisinde farklı katlar arasında dahi örgü harcı mekanik özellikleri değişkenlik göstermektedir [7].

Deprem kuvveti altında, zemin tarafından yanal ötelenmesi engellenmeyen veya rijitliği diğer katlardan çok küçük olan, diğer katlara göre maksimum kesme kuvvetinin etkisinde olan en alt kat, kritik kat olarak tanımlanmaktadır [8]. Kargir malzemelerin kalite farklılıklarından dolayı, farklı mekanik özelliklere sahip olması; dayanımı düşük duvarların devrilme veya göçme riskini artırmaktadır [9]. Duvar dayanımını etkileyen örgü harcının katlar arasında farklılık oluşturması durumunda düşük dayanımlı örgü harcı kritik kat belirlemede önemli rol oynamaktadır.

Meydana gelen ve yıkıcı etkisi olan birçok deprem sonrası yığma binalar üzerine yapılmış çok sayıda çalışma söz konusudur [10-12]. Deprem sonrası gözlenen yapısal davranış ve oluşan hasarlara ilişkin lokal saha çalışma verileri, hasar tespitine esas olan birçok parametre ve öneriler literatür çalışmalarında yer almaktadır $[13,14]$. Günümüzde yığma bir binanın yanal kuvvetlere karşı deprem performansı sadece duvarlarının deneysel verilerine dayanmayan, tuğla cinsine ve örgü harcı dayanımına göre şartnamelerde önerilen kesme performansına bağlı olarak değerlendirilmektedir [15,16]. Yığma binada yanal kuvvetlere karşı koymasını sağlayan kesme dayanımı, tuğla ile örgü harcı arasındaki aderansla oluşan bağ kuvveti ve bu bağın kopması sonrasında ise oluşan kalıcı sürtünme kuvvetidir [17]. Dolayısıyla mevcut binaların deprem performansının belirlenmesinde, en zayıf halka olan örgü harcı ile tuğla arasındaki kesme mukavemetinin belirlenmesinde, ASTM C 1531-03 ve core deneyi gibi deneysel model ve yöntemlerin kullanılmaktadır [18-20]. Ancak, örgü harcı ile tuğla arasındaki kesme mukavemetini belirlemek için önerilen bu deneysel yöntemler tahribatlı yöntemler olup, zaman ve maliyet bakımından uygulanabilirliği sınırlıdır [21].

Yığma bir binanın deprem performansı analizinde kullanılmak üzere TBDY 2018'e göre örgü harcı basınç dayanımına bağlı olarak kesme mukavemetinin tayini ya da hasarlı deney yöntemlerinden birinin yapılması gerekmektedir. Halihazırda kullanılmakta olan yığma binaların üzerinde tahribatlı deney yöntemlerinin kullanılması bina sakinlerini rahatsız etmektedir. $\mathrm{Bu}$ deneysel çalışma ile hasarlı yöntemle ortaya çıkan olumsuzlukları ortadan kaldırmak ve duvarın kesme dayanımını belirlemek için yerinde daha hızlı, pratik ve hasarsız bir alternatif test yöntemi geliştirerek literatüre katkı sağlayacaktır. Mevcut bir yığma bina üzerinde binanın dört farklı lokasyonundan ASTM C 1531-03 benzeri tahribatlı deney yöntemiyle kesme gerilmelerinin bulunması ve tahribatsız deney yöntemlerinden N-Schmidt çekici ile duvarların örgü harcı ve sıva harcının R okuma değerlerine ve bina ölü yüküne dayalı olarak duvar kesme dayanımının hızlı şekilde belirlenmesi amaçlanmıştır. Bu amaç doğrultusunda tahribatlı deney yöntemiyle tahribatsız deneyler ve değişkenler arasında uyumlu bir bağıntı ortaya konmuştur [20-22].

\section{Malzeme ve Yöntem}

\subsection{Yapısal Özellikler}

Mevcut bir yığma bina üzerinde kesme gerilmesinin hasarsız yöntemler kullanılarak hızlı belirlenmesine yönelik yapılan bu çalışmanın yapıldı̆̆ı bina 1950 yılında Ankara'nın Çankaya ilçesinde, yaklaşık olarak 19.50x11.00 m taban oturan alanında ve 5 katlı olarak inşa edilmiştir. Binanın yapımında katlarda 215x102x65 mm boyutunda dolu harman tuğlası kullanılırken, binanın en üst katında dolu tuğla ile aynı ebatlara sahip boşluk oranı \%35'ten az düşey delikli harman tuğlası kullanılmıştır. Sıva dahil duvar kalınlığı yaklaşık $27 \mathrm{~cm}$ olup, tuğlaları birbirine bağlayan derz örgü harcı kalınlığı 1,5-2 cm ve duvar örtüsü sıva harcı kalınlığı 2-3 cm arasında değişkenlik göstermiştir (Şekil 1). 


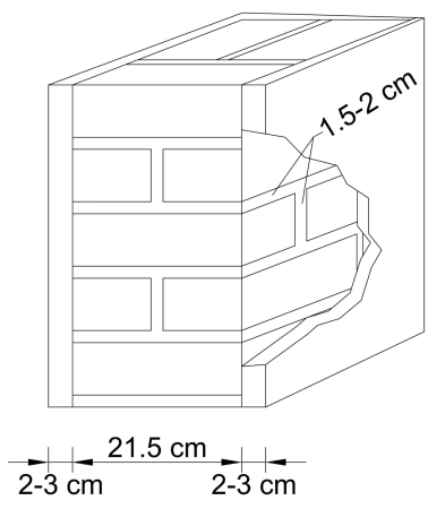

Şekil 1. Duvar kesit görünümü

\subsection{Deneysel Yöntem}

Mevcut bir yı̆̆ma bina üzerinde farklı katlarda oluşan kesme gerilmesinin tespiti için tahribatlı deneyler, kesme gerilmesinin tahmini içinse eksenel gerilme hesaplanarak tahribatsız deneyler yapılmıştır.

\subsubsection{Eksenel Gerilme Hesabı ve Tahribatsız Deney}

Kesme gerilmesinin değişkenlik göstermesinde, örgü harcı ve tuğla arasındaki bağlanma kalitesinin yanı sıra eksenel gerilmeler önemli faktör olarak etki etmektedir. Farklı katlarda yapılan deneylerden dolayı eksenel gerilmelerde katlara göre değişkenlik arz etmekte olup, katlardaki eksenel gerilmeler kat ağırlıkları bulunarak hesaplanmıştır. Ayrıca eksenel gerilmelerin doğruluğunun kontrolü için StatiCad modelleme ve analiz programıyla çözümleme yapılmıştır.

Bina inşası sırasında kullanılan yapı malzemelerinin farklı ocaklardan temin edilmiş olabileceği gibi, yapım esnasında uygulama faktörü dikkate alınarak, tuğlaların hem sınıf olarak hem de mekanik özellikleri bakımından değişkenlik gösterebileceği düşüncesi ile tahribatsız deney yöntemlerinden biri olan N-Schmidt test çekici ile (R) geri sekme okumaları yapılmıştır. Tuğla, sıva harcı ve örgü harcı için ayrı ayrı 12'şer adet olmak üzere N-Schmidt çekici ile okumalar alınmış, bu okumalardan maksimum ve minimum R değerleri hesaba katılmadan kalan diğer $10 \mathrm{R}$ değerinin ortalaması hesaplanmıştır [22].

Şekil 2. Tuğla duvar itme-kesme deney düzeneği
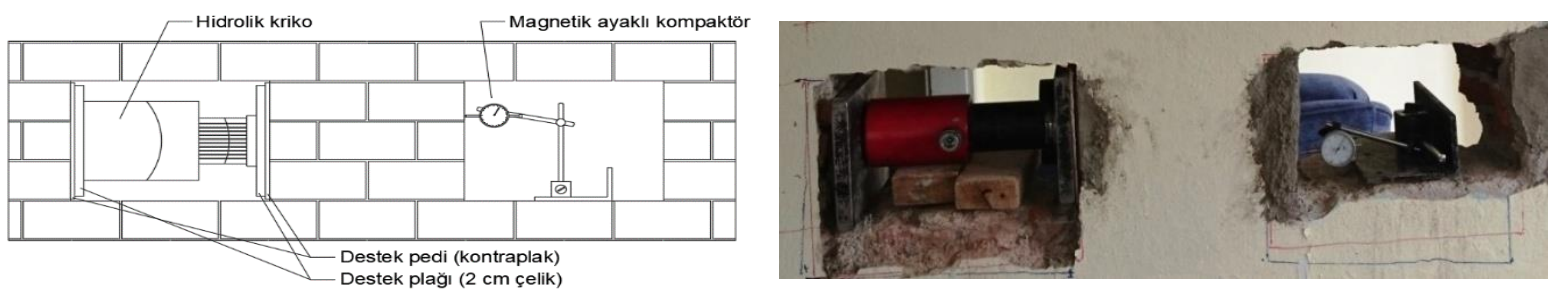

\subsubsection{Tahribatlı Deney}

Bu çalışmada kesme dört farklı kattaki kesme gerilmelerinin bulunması için tahribatlı deney düzeneğiyle her kat için bir test yapılmıştır. Tahribatlı deney olarak Şekil 2'de gösterildiği gibi, ASTM C 1531-03 standardı Metot-B deney düzeneğine benzer test düzeneği kullanılmıştır [20]. Standart deney düzeneğinden farklı olarak, standartta kullanılan tek tuğla yerine üst üste 3 tuğla birlikte itilmiş ve tek tuğlaya oranla numune hazırlama hatalarını minimiz edebilmek için sürtünme yüzeyi daha büyütülerek, sıralı 2 boy tuğlayı itmek üzere bir deney düzeneği tasarlanmıştır. 


\section{Bulgular ve Tartışma \\ 3.1 Tahribatsız Deney Sonuçları}

Tuğla, örgü harcı ve sıva harcı üzerinde yapılan tahribatsız deney okumalarına dair veriler Tablo 1 yer

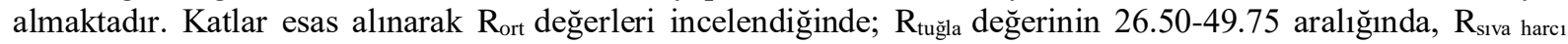

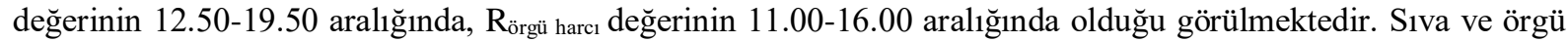
harcı R değerlerinin genel ortalamasının tuğla R değerlerinin genel ortalamasına oranlandığında \%50'sinden daha az olduğu, yer yer 1/3’ünden dahi küçük değerlerde kaydedildiği görülmektedir (Tablo 1).

Tablo 1. N-Schmidt Test Çekici R okuma değerleri.

\begin{tabular}{|l|c|c|c|}
\hline & $\mathbf{R}_{\text {tuğla }}$ & $\mathbf{R}_{\text {sıva harcı }}$ & $\mathbf{R}_{\text {örgü harcı }}$ \\
\hline 2. Kat & 26.50 & 19.50 & 12.00 \\
\hline 3. Kat & 32.50 & 15.25 & 11.00 \\
\hline 4. Kat & 28.50 & 15.00 & 16.00 \\
\hline 5. Kat & 49.75 & 12.50 & 12.00 \\
\hline Rort & $\mathbf{3 4 . 3 1}$ & $\mathbf{1 5 . 5 7}$ & $\mathbf{1 3 . 2 5}$ \\
\hline
\end{tabular}

Deneyler esnasında tuğlalarda herhangi bir kesme göçmesinin gözlenmemiş olması ve R değerlerine bakıldığında, duvarın kesme performansındaki etken parametrenin, en düşük mukavemeti ile birinci dereceden örgü ve sıva harcının olacağı görülmüştür.

Hasarsız deney yöntemi olan test çekici betonarme elemanlarda beton yüzeyinde karbonlaşma ile ortaya çıkan dayanım artışına ve iri agregalara rastlamasına bağlı olarak daha yüksek sonuçlar vermesi nedeniyle, etriye içerisinde kalan çekirdek bölgesinin dayanımını vermediği için kullanılması uygun görülmemektedir. Ancak sıva 2-3 cm kalınlığında ve $D_{\max }=1-3$ mm'lik yüzeysel bir kaplama malzemesi olduğundan, 2-3 cm ile sinırlı olan karbonatlaşmadan sıva \%100 etkileneceğinden hasarsız deney yöntemi olan test çekici sağlıklı sonuçlar verdiği, örgü harcı ise iç ve dış sıvalar arasında kaldığı için karbonatlaşmadan etkilenmeyeceğinden çekiç okumaları örgü harcının tüm özelliğini yansıttığı kabul edilmiştir.

\subsection{Eksenel Gerilme $(\sigma)$ ve $\operatorname{Kesme} \operatorname{Gerilmesi}(\tau)$}

Mevcut bir yığma bina üzerinde kesme gerilmesinin hasarsız yöntemler kullanılarak hızlı belirlenmesine yönelik yapılan bu çalışmada, ASTM C 1531-03 deneysel yöntemine benzer bir yöntemle kesme gerilmesi belirlenmiş olup, yığma binanın kat adedi ve deneyin yapıldığ 1 kata göre numune üzerine gelen eksenel düşey gerilmelerine, tuğla, sıva ve örgü harcının dayanımına ilişkin N-Schmidt çekici (R) okumalarına bağlı olarak hesaplanmıştır. Deneysel çalışmanın sonucunda elde edilen maksimum kesme gerilmesinin ve eksenel gerilmenin hesaplanması Doğan ve Odacıoğlu (2019) çalışmasına benzer şekilde yapılmıştır [7]. Alt katlara inildikçe duvar üzerine gelen düşey eksenel gerilmeler arttığından, katlara göre numune üzerine gelen eksenel düşey gerilmeleri bilgisayar modellemesi yapılarak bulunmuş ve ayrıca elle de hesaplanarak kontrolleri yapılmıştır. Hesaplanan düşey eksenel gerilmeler $\left(\sigma_{n}\right)$ ve shove deneyi sonucunda elde edilen yatay kesme gerilmeleri $\left(\tau_{u}\right)$ her kat için Tablo 2'de verilmiştir.

Tablo 2. Katlara göre numunelere etkiyen düşey eksenel $\left(\boldsymbol{\sigma}_{\boldsymbol{n}}\right)$ ve yatay kesme $\left(\boldsymbol{\tau}_{\boldsymbol{u}}\right)$ gerilmeleri.

\begin{tabular}{|l|c|c|}
\hline & $\boldsymbol{\sigma}_{\boldsymbol{n}}(\mathbf{M P a})$ & $\boldsymbol{\tau}_{\boldsymbol{u}}(\mathbf{M P a})$ \\
\hline 2. Kat & 0.44 & 0.66 \\
\hline 3. Kat & 0.32 & 0.61 \\
\hline 4. Kat & 0.20 & 0.76 \\
\hline 5. Kat & 0.09 & 0.52 \\
\hline
\end{tabular}

Üst katlara çıkıldıkça azalan düşey eksenel gerilme $\left(\sigma_{n}\right)^{\prime}$ ye bağlı olarak duvar kesme değerleri $\left(\tau_{u}\right)^{\prime}$ nin de azaldığı, duvarların kesme mukavemetinin, tuğlanın $\mathrm{R}$ değerlerindeki değişmelerden hemen hemen hiç etkilenmezken, sıvanın R değerinden çok az etkilendiği görülmüştür. Ancak örgü harcının R değerlerinin diğer 
katlarda 11-12 iken 4. katta 16'ya çıkması ile duvarın kesme değerinin artarak büyük oranda etkilendiği tespit edilmiştir. Deney modelinin de bir sonucu olarak, beklendiği üzere, göçmenin yatay olarak, duvarın en zayıf halkası olan örgü harcı düzleminde meydana geldiği görülmüştür.

\subsection{Regresyon Analizi}

Örgü ve sıva harcının basınç dayanımının yani R değerlerinin tuğladan daha düşük olması nedeniyle, deney düzeneği de ona göre tasarlanmış ve duvar üzerine gelen yanal yükleri örgü ve sıva harcının birlikte karşılaması, yatay kesme göçmesinin de yatay düzleminde örgü harcı-tuğla birleşim noktaların da gerçekleşmesi sağlanmıştır. Duvar basınç mukavemetini gösteren ortalama $\left(\mathrm{R}_{\mathrm{ort}}\right)$ okumaları hesaplanırken, örgü ve sıva kalınlıkları oranında etkidiği düşünülerek, Denklem 1 kullanılmıştır. Burada $R_{\text {ort }}$ değeri binanın tüm katlarının $\mathrm{R}$ okumalarının ortalaması olarak hesaplanmıştır.

$$
R_{\text {ort }}=R_{\text {örgüharcl }} \frac{t_{\text {orgüharcl }}}{t_{\text {duvar }}}+R_{\text {slva }} \frac{t_{\text {slva harcl }}}{t_{\text {duvar }}}
$$

Binanın örgü ve sıva harcı $R$ değerlerinin fazla değişken olmadığı kabul edilerek, binanın tamamı için bir $R_{\text {ort }}$ hesaplanmıştır. Bu denklem kullanılarak binanın tamamı için kesme yüzeyindeki örgü harcı genişliği 1 tuğla boyu

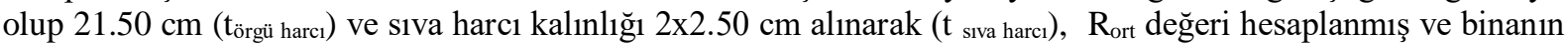
genel ortalaması olarak da 13.68 olarak bulunmuştur.

$\mathrm{R}_{\text {ort }}$ ile duvarın basınç mukavemeti $\left(f_{\mathrm{ck}}\right)$ arasındaki bağıntı kullanılmış ve tuğla basınç dayanımının 36.43 $\mathrm{MPa}$, örgü ve sıva harcı basınç dayanımının genel ortalaması yaklaşık $10.12 \mathrm{MPa}$ olarak bulunmuş ve her kat için $\mathrm{R}_{\text {ort }}$ ve duvarların $\mathrm{f}_{\mathrm{ck}}$ değerleri Tablo 3 'te verilmiştir. Bulunan dayanımlar zaman faktörü 0.70 katsayısı da dikkate alındığında tuğlanın dayanımının yaklaşık $25 \mathrm{MPa}$, harç dayanımın ise yaklaşık $7 \mathrm{MPa}$ dolaylarında olduğu görülmüştür [23].

Tablo 3. Katlara göre $R_{\text {ort }}$ ve duvarların $f_{\text {ck }}$ değerleri.

\begin{tabular}{|c|c|c|c|c|}
\hline & $\mathbf{R}_{\text {siva harc1 }}$ & $\mathbf{R}_{\text {örgü harcl }}$ & Rort & $\mathbf{f}_{\text {ck }}(\mathbf{M P a})$ \\
\hline 2. Kat & 19.50 & 12.00 & 13.39 & 9.98 \\
\hline 3. Kat & 15.25 & 11.00 & 11.79 & 9.36 \\
\hline 4. Kat & 15.00 & 16.00 & 15.81 & 11.30 \\
\hline 5. Kat & 12.50 & 12.00 & 12.09 & 9.47 \\
\hline & 15.57 & 13.25 & 13.68 & 10.12 \\
\hline
\end{tabular}

$\mathrm{Bu}$ veriler 1şığında, yığma bina duvarlarının yatay kesme dayanımını etkileyen iki ana parametreden birincisinin binadan binaya değişken olan örgü ve sıva harcının $R_{\text {ort }}$ değeri, ikincisinin ise katlar arasında ve duvardan duvara değişkenlik gösteren düşey eksenel gerilmelerin olduğu düşünülerek, bu iki bağımsız ana değişkene bağlı olarak, bağımlı değişken olan ve shove deneyleri ile elde edilen duvarların kesme dayanımı arasında var olan matematiksel eşitliği ve bu eşitliğin uyumlu olup olmadığının ölçütü olan iyi bir regresyonun olup olmadığı araştırılmış ve bu bağımlı ve bağımsız değişkenler arasındaki matematiksel eşitlik Denklem 2'de verilmiştir. Shove deneyi sonucunda elde edilen duvar kesme dayanımı ile elde edilen matematiksel denklem arasındaki uyumluluğu gösteren $\mathrm{R}^{2}$ değerinin 0,936 olduğu görülmüştür.

$$
\tau_{u}=0.25 \sigma_{n}+0.05 R_{\text {ort }}-0.078
$$

Burada katlar arasında bağımsız değişkenlerin aşırı değişkenlik göstermesi durumunda, herhangi bir katının (özellikle en alt kritik katın) $R_{\text {ort }}$ değeri ve üzerindeki düşey eksenel gerilme bu denklemde yerine konmak suretiyle o katın duvar kesme değeri bulunabileceği gibi, bağımsız değişkenlerin fazla değişkenlik göstermemesi durumunda binanın tüm katlarının $\mathrm{R}_{\text {ort }}$ değeri kullanılarak, incelenmek istenen katın düşey eksenel gerilmesi dikkate alınarak duvarın kesme dayanımı belirlenebilecektir. Bir duvarın kesme dayanımını, hasarsız yöntemlerden $\mathrm{R}$ okuma değerine bağlı olarak, \%93,9 gibi iyi bir uyumla ortaya koyan bu denklemin, gerek riskli bina tespitinde, gerekse bina performans analizlerinde dikkate alınması daha doğru sonuçlara götürecektir. 
Denklem 3'te görüldüğü üzere, duvarın başlangıç kesme dayanımı olan $\tau_{0}$ değeri, Riskli Bina Tespiti 2013 (RBTE-2013)'te sadece duvarın cinsi ve delik oranına bağlı olarak sabit değerler ile risk analizi hesaplarında alınması önerilirken, Türkiye Bina Deprem Yönetmeliği 2018 (TBDY-2018) ve Riskli Yapıların Tespit Edilmesine İlişkin Esaslar (RYTEIE 2019)'da sadece örgü harcının dayanımına bağlı olarak alınması önerilmektedir. Şartnameye göre örgü harcının basınç dayanımının yaklaşık 7 MPa değeri (M2-M9 kalitede) için $\tau_{0}$ değeri 0.2 olarak verilmektedir [16, 24, 25].

$$
\tau_{u}=\tau_{0}+0.4 \sigma_{n}
$$

Her kat için duvar kesme dayanımına ilişkin; shove testi sonuçları, matematiksel Denklem 2 sonuçları ve şartname de verilen Denklem 3 sonuçları Tablo 4'te verilmiştir. 4. kattaki duvarın kesme değerinin, $\mathrm{R}_{\text {ort }}$ değerine bağlı olarak, diğer katlara oranla daha yüksek çıkması göstermiştir ki; bir yığma bina için Denklem 2 kullanılarak, binanın genel $R_{\text {ort }}$ değeri kullanılarak tek bir kesme dayanımı hesaplamak yerine, her katın ayrı ayrı $R_{\text {ort }}$ değeri dikkate alınarak her katın duvarlarının kesme dayanımını hesaplamanın daha güvenilir sonuçlar vereceği görülmüştür.

Tablo 4. Katlara göre numunelere etkiyen düşey eksenel $\left(\sigma_{\mathrm{n}}\right)$ ve yatay kesme $\left(\tau_{\mathrm{u}}\right)$ gerilmeleri.

\begin{tabular}{|c|c|c|c|c|c|}
\hline Kat & $\sigma_{\mathbf{n}}$ & $\begin{array}{c}\text { Shove Deney } \\
\text { Sonuçları } \\
\tau_{\mathrm{u}}(\mathrm{MPa})\end{array}$ & $\begin{array}{c}\text { Genel Rort için } \\
\text { Denklem 2 } \\
\tau_{\mathrm{u}}(\mathrm{MPa})\end{array}$ & $\begin{array}{c}\text { Her Katın Rort için } \\
\text { Denklem } 2 \\
\tau_{\mathrm{u}}(\mathbf{M P a})\end{array}$ & $\begin{array}{c}\text { TBDY -2018 } \\
\tau_{0}=0.2 \\
\tau_{\mathrm{u}}(\mathrm{MPa})\end{array}$ \\
\hline 2. Kat & 0.44 & 0.66 & 0.72 & 0.70 & 0.38 \\
\hline 3. Kat & 0.32 & 0.61 & 0.69 & 0.59 & 0.33 \\
\hline 4. Kat & 0.20 & 0.76 & 0.66 & 0.76 & 0.28 \\
\hline 5. Kat & $\begin{array}{l}0.09 \\
\end{array}$ & 0.52 & 0.63 & 0.55 & 0.24 \\
\hline
\end{tabular}

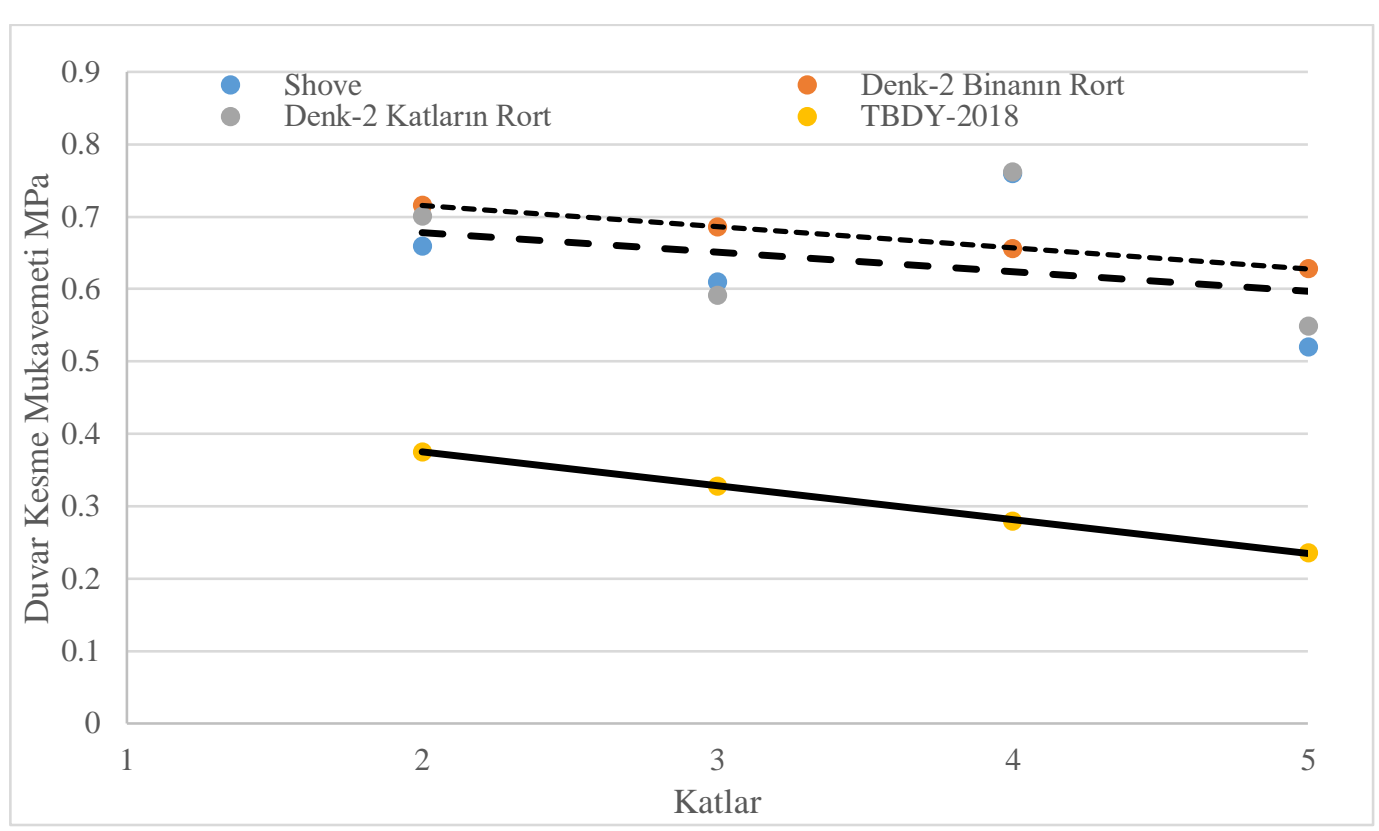

Şekil 3. Katlara Göre Duvar Kesme Gerilmeleri.

Hem shove test sonucunda bulunan hem de matematiksel Denklem 2 ile hesaplanan duvarların kesme mukavemetinin, TBDY-2018'de verilen Denklem 3'e göre bulunan sonuçların üzerinde kaldığı görülmüștür. Şartnamelerde verilen duvar kesme mukavemetinin, katlar için elde edilen matematiksel denklem ile elde edilen bulgulara oranının \%37-56 aralığında değiştiği, yani en güçlü 4. katı için güvenlik katsayısının 2.71, en zayıf olan 3. kat için ise güvenlik katsayısının 1.80 olduğu görülmüştür. Sonuç olarak şartnamelerimizde belirtilen yığma 
duvarların kesme değerlerinin oldukça düşük hesaplandığı, diğer bir deyişle şartnamelerimizin oldukça güvenli tarafta kaldığı görülmüştür (Şekil 3).

Risk sınırına yakın yığma bir binanın deprem riski oranının yüksek olarak hesaplanması, güvenli tarafta kalmak adına doğru bir hesap gibi görülse de burada olduğu gibi yaklaşık iki katı ve hatta daha yüksek güvenilirlikle bir binanın da riskli çıkarılarak yıkılması da ekonomik bir tespit olmayacaktır.

\section{Sonuçlar}

Ülkemizde farklı malzeme ve iş̧̧ilikle yapılmış çimento katkılı örgü harçlı yığma binalarda, kesme mukavemeti binadan binaya çok büyük değişkenlikler arz etmektedir. Yı̆ğma bir binanın deprem performansı analizinde kullanılmak üzere TBDY 2018'e göre örgü harcı basınç dayanımına bağlı olarak kesme mukavemetinin tayini ya da hasarlı deney yöntemlerinden birinin yapılması gerekmektedir. Bu deneysel çalışma ile hasarlı yöntemle ortaya çıkan olumsuzlukları ortadan kaldırmak ve duvarın kesme dayanımını belirlemek için yerinde daha hızlı, pratik ve hasarsız bir alternatif test yöntemi geliştirmiştir.

20. YY. ikinci yarısında yapılmış olan 5 katlı mevcut bir yığma bina üzerinde kesme gerilmesinin hasarsız yöntemler kullanılarak hızlı belirlenmesine yönelik yapılan bu çalışmada:

- Tuğlalarda herhangi bir kesme göçmesinin gözlenmemiş olması ve R değerlerine bakıldığında, duvarın kesme performansındaki etken parametrenin, en düşük mukavemeti ile birinci dereceden örgü ve sıva harcının olacağ 1 ve göçmenin duvarın en zayıf halkası olan örgü harcı düzleminde meydana geldiği görülmüş,

- Üst katlara çıkıldıkça azalan düşey eksenel gerilmeye bağlı olarak duvar kesme değerlerinin de azaldığı, duvarların kesme mukavemetinin, tuğlanın $\mathrm{R}$ değerlerindeki değişmelerden hemen hemen hiç etkilenmediği, ancak örgü ve sıva harcının R değerlerinden büyük oranda etkilendiği görülmüş,

- ASTM C 1531-03 deneysel yöntemine benzer bir yöntemle duvarın kesme gerilmesi belirlenmiş, duvarların kesme dayanımını ile örgü ve sıva harcının $\mathrm{R}_{\text {ort }}$ değeri ve duvara gelen eksenel düşey gerilme arasında $\% 93.9$ gibi iyi bir uyumla uyumlu bir matematiksel denklem elde edilmiş,

- Hem shove test sonucunda bulunan hem de matematiksel Denklem 2 ile hesaplanan duvarların kesme mukavemetinin, TBDY-2018'de verilen Denklem 3'e göre bulunan sonuçların üzerinde kaldığı görülmüş ve şartnamelerde verilen duvar kesme mukavemetinin, katlar için elde edilen matematiksel denklemle elde edilen bulgulara oranının \%50-73 aralığında değiştiği, yani en güçlü 4. katı için güvenlik katsayısının 2 , en zayıf olan 3. katta ta ise güvenlik katsayısının 1.37 olduğu görülmüştür.

Sonuç olarak şartnamelerimizde belirtilen yığma duvarların kesme değerlerinin oldukça düşük hesaplandığı, diğer bir deyişle şartnamelerimizin oldukça güvenli tarafta kaldığı tespit edilmiştir.

Risk sınırına yakın yığma bir binanın deprem riski oranının yüksek olarak hesaplanması, güvenli tarafta kalmak adına doğru bir hesap gibi görülse de burada olduğu gibi yaklaşık iki katı ve hatta daha yüksek güvenilirlikle bir binanın da riskli çıkarılarak yıkılması da ekonomik bir tespit olmayacaktır.

$\mathrm{Bu}$ bakımdan benzer çalışmaların farklı tuğla ve harçlarla inşa edilmiş farklı binalar üzerinde yapılması, mevcut bina risk analizlerine ilişkin elde edilen duvarlarının kesme mukavemetini veren bağıntının güvenilirliğini artıracak, böylece Türkiye özelinde yapılmış oldukça değişkenlik arz eden yığma binaların daha bilimsel risk analizlerinin yapılmasını mümkün kılacaktır.

\section{Kaynaklar}

[1] Can Ö. Investigation of seismic performance of in-plane aligned masonry panels strengthened with Carbon Fiber Reinforced Polymer. Construction and Building Materials, 2018, 186: 854-862.

[2] Akgül M, Doğan O. Yığma yapılarda güçlendirme yöntemleri ve TBDY-2018'de yığma yapılar. Munzur 1. Uluslararası Uygulamalı Bilimler Kongresi; 24-26 Mayıs 2019; Tunceli, Türkiye. 73-86.

[3] Göker Ş, Karaşin A. Depremde hasar gören kırsal yapılar için bir yapısal hasar değerlendirmesi. DÜMF Mühendislik Dergisi 2015; 6(1): 31-38.

[4] Haach, V.G, Vasconcelos G, Lourenço P.B. Influence of aggregates grading and water/cement ratio in workability and hardened properties of mortars. Construction and Building Materials 2011; 25(6): 2980-2987.

[5] Berhane Z. Evaporation of water from fresh mortar and concrete at different environmental conditions. Journal proceedings 1984; 81(6): 560-565.

[6] Almusallam, A. A. Effect of environmental conditions on the properties of fresh and hardened concrete. Cement and Concrete composites 2001; 23(4-5): 353-361. 
[7] Doğan O, Odacioğlu O.G. An Experimental Study To Determine Sliding Shear Strength And Internal Frictional Coefficient Of Clay Brick Wall In A Masonry Building. Uluslararası Mühendislik Araştırma ve Geliştirme Dergisi UMAGD 2019; 11(2): 670-676.

[8] Akgül M, Doğan O. Altındağ/Ankara Özelinde Tipik Yığma Binaların Deprem Risklerinin 2018 Türkiye Bina Deprem Yönetmeliğine Göre İncelenmesi. NWSAENS 2020; 15(1):1-14.

[9] Akgül M, Doğan O. 4 Nisan 2019 Elazığ-Sivrice Depreminin Yığma Yapılara Etkisinin Değerlendirilmesi. Uluslararası Mühendislik Araştırma ve Geliştirme Dergisi UMAGD2020; 12(1): 265-277.

[10] Yön B, Onat O. 3 Aralık 2015 Bingöl-Kiğı depreminin Tunceli ilindeki yığma yapılara etkisinin değerlendirilmesi. Dicle Üniversitesi Mühendislik Fakültesi Mühendislik Dergisi 2018; 9 (1): 375-385. Retrieved from https://dergipark.org.tr/en/pub/dumf/issue/36316/412703

[11] Sayın E, Yön B, Calayır Y, Gör M. Construction failures of masonry and adobe buildings during the 2011 Van earthquakes in Turkey. Structural Engineering and Mechanics 2014; 51(3): 503-518.

[12] Güney D, Aydin E, OzturkB. The evaluation of damage mechanism of unreinforced masonry buildings after Van(2011) and Elazig (2010) Earthquakes. 11th International Conference on Damage Assessment of Structures (DAMAS 2015);2015; Ghent, Belgium.

[13] Jagadish K. S, Raghunath S, Nanjunda Rao K.S. Behaviour of masonry structures during the Bhuj earthquake of january 2001. Journal of Earth System Science 2003;112(3): 431-440.

[14] BayraktarA, Çoşkun N, Yalçın A. Performance of Masonry Stone Buildings during the March 25 and 282004 Aşkale (Erzurum) Earthquake in Turkey. Journal of performance of constructed facilities 2007; 21(6). doi:10.1061/(ASCE)08873828(2007)21:6(432).

[15] TDY 2007. Deprem Bölgelerinde Yapılacak Binalar Hakkında Yönetmelik. Ankara: Bayındırlık ve İskan Bakanlı̆̆ı, 2007.

[16] TBDY 2018. Türkiye Deprem Bölgelerinde Yapılacak Binalar Hakkında Yönetmelik. Ankara :Afet ve Acil Durum Yönetim Başkanlığ 1 , 2018.

[17] Bayülke N. Yı̆gma Yapılar - Taş ve Tuğla.İnşaat Mühendisleri Odası Ankara Şube, Ankara, Türkiye, 2013.

[18] Schuller M.P, Atkinson R.H, Noland J. L. Structural evaluation of historic masonry buildings. APT Bulletin: The Journal of Preservation Technology 1995; 26(2/3):51-61.

[19] Mazzotti C, Sassoni E, Pagliai G. Determination of shear strength of historic masonries by moderately destructive testing of masonry cores. Construction and Building Materials 2014; 54: 421-431.

[20] ASTM C1531-03. Standard Test Method for In Situ Measurement of Masonry Joint Shear Strength Index. West Conshohocken, United States. ASTM International, 2003.

[21] Aköz F. Yığma Kagir Yapılarda Hasar Tespiti. YDGA2005, Orta Doğu Teknik Üniversitesi, Ankara,Türkiye, 2005.

[22] TS EN 12504-2. Yapılarda beton deneyleri - Bölüm 2: Tahribatsız muayene - Geri sıçrama sayısının belirlenmesi. Ankara : Türk Standatları Enstitüsü, 2014.

[23] Erdoğan Y.T. 2003. Beton, Metu Pres, Ankara.

[24] RBTE-2013. Riskli Bina Tespit Esasları. Afet Riski Altındaki Alanların Dönüştürülmesi Hakkında Kanunun Uygulama Yönetmeliğinde Değişiklik Yapılmasına Dair Yönetmelik. Çevre ve Şehircilik Bakanlığı.

[25] RYTEIE - 2019. Riskli Yapıların Tespit Edilmesine İlişkin Esaslar. Çevre ve Şehircilik Bakanlığı. 